\author{
Research Article \\ www.ijrap.net
}

\title{
PLANT REGENERATION STUDIES IN SAFED MUSLI (CHLOROPHYTUM SP.)
}

Pal Minakshi ${ }^{1}$, Sethi Neeraj ${ }^{2} *$, Kaura Sushila ${ }^{3}$, Parle Milind ${ }^{3}$

${ }^{1}$ Centre for Plant Biotech, Hisar, Haryana, India

${ }^{2}$ Department of Bio and Nano Technology, Guru Jambheshwar University of Science and Technology, Hisar, Haryana, India

${ }^{3}$ Pharmacology Division, Dept. Pharm. Sciences, Guru Jambheshwar University of Science and Technology, Hisar, Haryana, India

Received on: 17/12/13 Revised on: 23/01/14 Accepted on: 20/02/14

*Corresponding author

Neeraj Sethi, PhD Scholar (CSIR SRF), Department of Bio and Nano Technology, Guru Jambheshwar University of Science and Technology, Hisar, Haryana, India Email: 20neerajsethi@gmail.com

DOI: $10.7897 / 2277-4343.05119$

\section{ABSTRACT}

An efficient protocol was developed for the rapid in vitro multiplication of an endangered medicinal herb, Chlorophytum borivilianum (safed musli); by using Basal/crown plate explants. The effects of phytohormones [6-benzylaminopurine (BAP), kinetin (KN), indole-3-acetic acid (IAA), indole-3butyric acid (IBA) or $\alpha$-naphthalene acetic acid (NAA)] on in vitro regeneration were investigated. The highest number of shoots (21.67), maximum shoot length $(13.14 \mathrm{~cm})$ and the highest response of shoot induction $(85 \%)$ were recorded on MS medium supplemented with $3.0 \mathrm{mg} / \mathrm{l}$ BAP and 2.0 $\mathrm{mg} / \mathrm{l} \mathrm{KIN}$. Rooting was best achieved on half-strength MS medium augmented without plant growth regulators IBA and sucrose (3 \%, w/v). The plantlets regenerated in vitro with well-developed shoot and roots were successfully established in pots containing sterile sand and coco peat (1:1) and grown in a greenhouse with $85 \%$ survival rate. The regenerated plants did not show any detectable morphological variation. The developed method can be successfully employed for large-scale multiplication and conservation of C. borivilianum.

Keywords: Chlorophytum borivilianum, Micro propagation, Basal/Crown explants, Kinetin, BAP, IAA.

\section{INTRODUCTION}

Plant tissue culture is the established technique of in vitro maintenance and growth of plant cells, tissues or organs under aseptic conditions on artificial nutrient medium in a suitable container under the control environmental conditions. The technique of plant cell culture occupies the key role in the second green revolution in which gene modification and biotechnology are being used to improve crop yield and quality. The application of tissue culture techniques for the biosynthesis of secondary metabolites, particularly in the plants of pharmaceutical significance, holds an interesting alternative for controlled product of plant constituents. In the recent years, it has become increasingly difficult to maintain constant supply of many of the important medicinal plants due to several factors, such as, their ruthless exploitation, lack of conservation of environment, increasing cost of labour and economical and technical problems associated with the cultivation of medicinal plants. On the other hand, techniques of plant tissue culture can provide ever lasting solution to some of the burgeoning problems in the area of plant biotechnology. Medicinal plant Chlorophytum borivilianum (Safed Musli) is endogenous medicinal plant to India and considered as a 'white gold' or 'divya aushad' in Indian systems of medicine ${ }^{1}$. It is distributed in eastern part of India (Assam, Eastern Ghats, Eastern Himalayas, Bihar and Andhra Pradesh ${ }^{2} .13$ species are reported to occur in India of which 8 are endemic ${ }^{3}$. It belongs to family Liliaceae and is valued for dried fasciculated storage roots ${ }^{4}$. It is an endangered species ${ }^{5}$. $C$. borivilianum is a small herbaceous plant. The major contents of safed musli are carbohydrate (42\%), proteins $(8-9 \%)$, root fibers $(3-4 \%)$ and saponins $(2.17 \%)^{5}$. It is an aphrodisiac drug used to cure general debility. Recently, C.borivilianum has gained a well established domestic (Indian) and international market for being the herbal alternative of "Viagra" without any side effects. It is a remedy for diabetes, for rheumatism and joint pains ${ }^{6}$. It is antimicrobial, anti-inflammatory and antitumor agent ${ }^{7}$. The roots of plants are currently sold in market at a price of Rs. $600-700 / \mathrm{kg}$. The overuse of C. borivilianum species made it rapidly decreasing. This herb is traditionally grown through tuberous root that have become scarce in nature. Moreover seed germination is only $14-16 \%$. Poor seed setting, germination and slow growth in conventional vegetative propagation are major constraints in the large-scale cultivation of this commercially important medicinal plant ${ }^{8}$. High frequency multiplication through plant tissue culture technique would minimize the damage to remnant populations. In this context, an efficient micropropagation protocol has been developed for rapid multiplication and conservation of C. borivilianum.

\section{MATERIALS AND METHODS \\ Plant material}

Basal/Crown plate and peduncle of $C$. borivilianum were collected from mature plants grown in medicinal and aromatic plant section of the department of plant breeding CCS Haryana Agriculture University. The explants were washed in running tap water for at least 25 minutes and then soaked in a $5 \%(\mathrm{v} / \mathrm{v})$ detergent, labolene (Qualigens, India) for 10 minutes. Surface sterilization of the explant was done with $\mathrm{KMnO}_{4}$ for 10 minutes followed by treatment with $0.1 \% \mathrm{HgCl}_{2}(\mathrm{w} / \mathrm{v})$ for $8-10$ minutes and rinsed thoroughly (4 times) with sterile distilled water. All 
the disinfection operation was carried out in the horizontal laminar flow cabinet.

\section{Culture medium and Culture conditions}

The explants were cultured on Murashige and Skoog's medium supplemented with various phytohormones viz. BAP, KN, IAA and IBA solidified with $0.8 \%$ agar 10 . Sucrose $(3 \%, \mathrm{w} / \mathrm{v})$ was used as carbon source and the $\mathrm{pH}$ of the medium was adjusted to 5.8 prior to the addition of gelling agent (Clarigel, $0.2 \%$, Himedia, India). All the media were autoclaved at $121^{\circ} \mathrm{C}$ for 20 minutes. All the cultures were maintained at $25 \pm 1{ }^{0} \mathrm{C}$ with $16 \mathrm{~h}$ light $/ 8 \mathrm{~h}$ dark photoperiod cycles with $45 \mu \mathrm{mol} \mathrm{m} \mathrm{m}^{-2} \mathrm{~S}^{-1}$ irradiation (Philips, India). All the experiments were repeated at least twice and data was collected after four weeks of culture. All of the experiments were repeated twice with 20 replicates per treatment. The cultures were observed periodically and morphological changes were recorded after 4 weeks of culture. The results were analyzed statistically.

\section{Shoot Multiplication}

The established explants were sub cultured and multiplication was observed in modified MS medium supplemented with different combination of growth regulators such as kinetin, IBA and BAP. The plantlets were then allowed to grow for 30 days.

\section{Induction of rooting and acclimatization}

Rooting was initiated in half strength MS medium containing different concentration of sucrose (w/v) supplemented with various concentrations and combinations of auxins (IBA, IAA and NAA). All the cultures were incubated for 16 hours at $24 \pm 2^{\circ} \mathrm{C}$ under fluorescent light. Number of roots per shoot was assessed after four weeks. Rooted plants were removed from culture media and washed to get rid of the media adhering over it. Regenerated plantlets were planted in plastic pots containing a mixture of loam soil, sand and vermicompost $(1: 1: 1 \mathrm{v} / \mathrm{v})$. The plantlets were hardened in presence of $90-95 \%$ relative humidity. The survival rate was assessed after four weeks of Plantation. Each experiment was repeated thrice.

\section{RESULTS AND DISCUSSION}

The morphogenetic responses of Basal/crown plate explants to various concentrations and combinations of phytohormones are summarized in Table 1. MS medium ${ }^{9}$ without phytohormones (control) failed to induce shoots from Basal/crown plate explants. The multiplication rate and shoot numbers are variable with type and concentration of phytohormones. All concentrations and combinations of phytohormones facilitated shoot bud differentiation (Figure 1A). Swelling of the explants took place within seven days and then differentiation into multiple shoots occurred within four weeks. Among the various cytokinins tested, BAP was found to be more efficient than others with respect to initiation and subsequent proliferation of shoots. Maximum numbers of shoots $(21.67 \mathrm{~cm})$, highest shoot length $(13.14 \mathrm{~cm})$ and maximum shoot induction response $(85 \%)$ were achieved on MS medium fortified with BAP $(3.0 \mathrm{mg} / \mathrm{l})$ and $\mathrm{KIN}$
(2.0 mg/l) within 28 days (Table 1, Figure 1-B, C). Upon lowering or higher concentrations of BAP, a reduction in the number of shoots per culture was recorded. MS basal media containing Kinetin $(2.0 \mathrm{mg} / \mathrm{l})$ showed $80 \%$ response. Whereas combination of BAP $(2.0 \mathrm{mg} / \mathrm{l})+$ Kinetin $(3.0 \mathrm{mg} / \mathrm{l})+$ IBA $(0.2 \mathrm{mg} / \mathrm{l})$ showed $61 \%$ response of shoot regeneration. The effect of cytokinin reduces the number of micro propagated shoots ${ }^{10}$. In the present study, BAP in combination with kinetin proved to be more effective for shoot development but some workers reported that BAP and kinetin combination developed fewer multiple shoots in some species. ${ }^{11}$

\section{Shoot multiplication}

The initiated shoot cultures were established and the effect of various concentration and combination of growth regulators on shoot multiplication was studied. Media were tried. The data of this experiment is presented in Table 2. MS medium supplemented with BAP (2.0 mg/l) and Kinetin $(3.0 \mathrm{mg} / \mathrm{l})$ was found to be best for shoot multiplication (Figure 1D). Average number of, well formed shoots per culture, was recorded 21.67 on MS medium containing BAP $(2.0 \mathrm{mg} / \mathrm{l})+\operatorname{Kinetin}(3.0 \mathrm{mg} / \mathrm{l})$ with agar as solidifying agent. 18.00 shoots per culture was obtained with MS + Kinetin (3.0 mg/l). In general, from a single shoot bud, 20-25 shoots were obtained in 25-30 days. By reducing the concentration of BAP and kinetin, numbers of shoots were also reduced. Lowest numbers of shoots (7.33) were recorded on MS medium containing BAP $(2.0 \mathrm{mg} / \mathrm{l})$ with agar as gelling agent. Thus experimental observation supports that MS medium containing low concentration of auxin along with cytokinin increase the rate of shoot multiplication ${ }^{12-16}$

\section{Root formation}

To optimize the rooting response of plantlets raised in vitro, different auxins (IAA, IBA, and NAA) were tested at various concentrations and combinations (Table 2). The rooting was significantly affected by the concentrations of IBA. Half-strength MS medium ${ }^{17,18}$ fortified with IBA $(1.0 \mathrm{mg} / \mathrm{l})$ was found most effective for induction of healthy roots. ${ }^{19-21}$ In this medium maximum root number $(8.1 \pm 0.7)$, maximum root length $(4.0 \pm 0.2)$ and highest rooting response $(100 \%)$ was also achieved (Table 2, Figure 1C). The roots on this medium were found to be thicker which has an added advantage during planting. NAA and IAA were poor for induction of roots in $C$. borivilianum. However, they showed significant root induction when combined with IBA. Shoot length, root length, number of leaves and shoot/root ratio were recorded after 25-30 days on half strength MS medium with different concentration of sugar. Half strength MS medium with sucrose $(30 \mathrm{~g} / \mathrm{l})$ was found to be best medium followed by MS medium with sucrose (20 g/l) (Table 3).

\section{Performance of tissue culture raised plants}

The data indicated that maximum mean shoot length $(13.14 \mathrm{~cm})$ was observed on MS medium containing sucrose $(30 \mathrm{~g} / \mathrm{l})$. Least shoot length $(9.71 \mathrm{~cm})$ was observed on medium containing half MS with sucrose (50 g/l) (Table 3). 
Table 1: Effect of different Plant growth regulators and there combinations with MS medium on shoot induction from basal/crown plate explant in safed musli

\begin{tabular}{|c|c|c|}
\hline S. No. & Media Composition (mg/l) & Percentage of explants producing shoots \\
\hline 1. & MS & - \\
\hline 2. & $\mathrm{MS}+\mathrm{BAP}(2.0)$ & 62 \\
\hline 3. & $\mathrm{MS}+\mathrm{BAP}(3.0)$ & 58 \\
\hline 4. & MS + Kinetin (2.0) & 80 \\
\hline 5. & MS + Kinetin (3.0) & 68 \\
\hline 6. & $\mathrm{MS}+\mathrm{BAP}(2.0)+\operatorname{IBA}(0.2)$ & 49 \\
\hline 7. & $\mathrm{MS}+\mathrm{BAP}(3.0)+\mathrm{IBA}(0.2)$ & 52 \\
\hline 8. & $\mathrm{MS}+\mathrm{BAP}(3.0)+$ Kinetin (2.0) & 85 \\
\hline 9. & MS + BAP (3.0) + Kinetin (3.0) & 79 \\
\hline 10. & MS + BAP (2.0) + Kinetin (3.0) & 73 \\
\hline 11. & $\mathrm{MS}+\mathrm{BAP}(4.0)+$ Kinetin (3.0) & 65 \\
\hline 12. & $\mathrm{MS}+\mathrm{BAP}(2.0)+$ Kinetin $(2.0)+\mathrm{IBA}(0.2)$ & 47 \\
\hline 13. & $\mathrm{MS}+\mathrm{BAP}(2.0)+$ Kinetin (3.0) + IBA (0.2) & 61 \\
\hline 14. & MS + Kinetin (2.0) + IBA (0.2) & 54 \\
\hline 15. & MS + Kinetin (2.0) + IBA $(0.1)$ & 59 \\
\hline
\end{tabular}

Table 2: Effect of different concentrations of Plant growth regulators added to the MS medium on shoot multiplication from basal/crown plate explant of safed musli

\begin{tabular}{|c|c|c|}
\hline S. No. & Media Composition (mg/l) & Mean no. of shoots /explants \\
\hline 1. & MS & - \\
\hline 2. & MS + BAP (2.0) & 7.67 \\
\hline 3. & MS + BAP (3.0) & 9.33 \\
\hline 4. & MS + Kinetin (2.0) & 15.50 \\
\hline 5. & MS + Kinetin (3.0) & 18.00 \\
\hline 6. & MS + BAP (2.0) + IBA (0.2) & 11.33 \\
\hline 7. & MS + BAP (3.0) + IBA (0.2) & 10.50 \\
\hline 8. & MS + BAP (3.0) + Kinetin (2.0) & 16.33 \\
\hline 9. & MS + BAP (2.0) + Kinetin (3.0) & 21.67 \\
\hline 10. & MS + Kinetin (3.0) + IBA (0.2) & 17.67 \\
\hline
\end{tabular}

Table 3: Effect of different concentration of sucrose added to the half strength MS media on rooting of In Vitro formed shoots of Safed Musli

\begin{tabular}{|c|c|c|c|}
\hline S. No. & Sucrose conc. (g/l) & Mean \% of shoots rooted & Mean shoot length (cm) \\
\hline 1. & 0 & - & - \\
\hline 2. & 10 & 65.33 & 10.34 \\
\hline 3. & 20 & 79.66 & 11.78 \\
\hline 4. & 30 & 89.20 & 13.14 \\
\hline 5. & 40 & 61.50 & 10.02 \\
\hline 6. & 50 & 50.00 & 9.71 \\
\hline
\end{tabular}
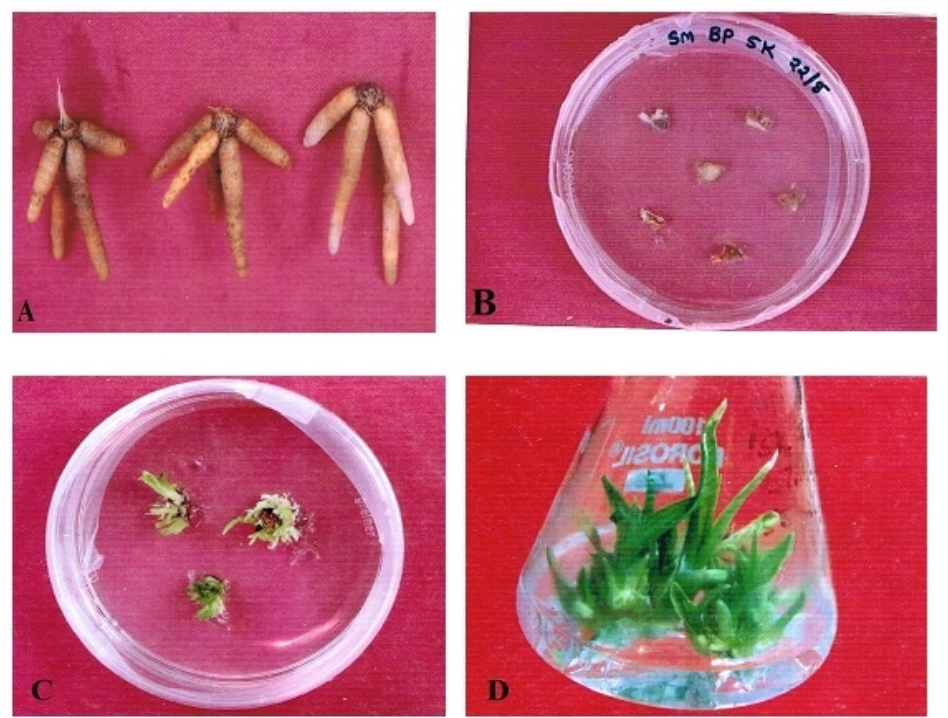

Figure 1 A: Basal/Crown Plate Explants used, Figure 1 B: Explants cultured on MS medium supplemented with [BAP (3.0 mg/l) + Kinetin (2.0 mg/l)] Figure $1 \mathrm{C}$ : Shoot initiation from explants cultured on MS medium supplemented with [BAP (3.0 mg/l) + Kinetin (2.0 mg/l)] Figure 1 D: Multiplication of shoot on MS medium supplemented with [BAP (2.0 mg/l) + Kinetin (3.0 mg/l)] 


\section{CONCLUSION}

We have used different concentration of growth regulators to establish a procedure for rapid in vitro regeneration of Safed Musli. Together, we have identified those different combinations of plant growth regulators that are highly efficient for shoot induction and shoot multiplication. Further we have developed an efficient method of rooting by using various concentration of sucrose in half MS basal media. Hence, this study will be fruitful in providing new technique for large scale production of Safed Musli.

\section{REFERENCES}

1. Khanam Z, Singh O, Singh R, Bhat IU. Safed musli (Chlorophytum borivilianum): A review of its botany, ethno pharmacology and phytochemistry. J Ethno Pharmacol 2013; 150(2): 421-41. http://dx.doi.org/10.1016/j.jep.2013.08.064

2. Garima V, Shruti SD. Micro propagation and field performance of Chlorophytum borivilianum. Int. Res. J. Pharm 2012; 3(8): 262-4.

3. Singh A and Chauhan HS. Safedmusli (Chlorophytum borivilianum) distribution, biodiversity and cultivation. J med aromatic Pl Sci 2003; 25: 712-9.

4. Nayar MP, Sastry ARK. Chlorophytum borivilianum. In: Nayar MP, Sastry ARK, Eds. Red data book of Indian plants, Vol. 2. Calcutta: Botanical Survey of India; 1988. p. 142.

5. Desale P. Safed Musli: Herbal Viagra for Male Impotence. Journal of Medicinal Plants Studies 2013; 1(3): 91-7.

6. Parle M, Kaura S. How to live with Rheumatoid Arthritis? Int. Res. J. Pharm 2012; 3(3): 115-12.

7. Thakur GS, Bag M, Sanodiya BS, Debnath M, Zacharia A, Bhadauriya P, Prasad GB, Bisen PS. Chlorophytum borivilianum: a white gold for biopharmaceuticals and neutraceuticals. Curr Pharm Biotechnol 2009; 10(7): 650-66. http://dx.doi.org/10.2174/138920109789542084

8. Rizvi MZ, Kukreja AK, Bisht NS. In vitro propagation of an endangered medicinal herb Chlorophytum borivilianum Sant. et Fernand through somatic embryogenesis. Physiol Mol Biol Plants 2010; 16(3): 249-57. http://dx.doi.org/10.1007/s12298-0100026-6

9. Murashige T, Skoog F. A revised medium for rapid growth and bioassays with tobacco tissue cultures. Physiol. Plant 1962; 15(3): 473-97. http://dx.doi.org/10.1111/j.1399-3054.1962.tb08052.x

10. Dunstan DI, Thorpe TA. Plant regeneration and genetic variability, In: Vasil IK (ed) Cell culture and somatic cell genetics of plants, vol. 3. Academic Press, Orlando; 1986. p. 223-41.
11. Shamsudeen, Varisai M, Jawahar M Thiruvengadam, Jeyakumar M, Jayabalan N. Effect of cytokinins on proliferation of multiple shoots in Macrotyloma uniflorum (Lam). J. Plant Biotechnol 1999; 1: 7983.

12. Rout GR, Saxena C, Samantaray S, Das P. Rapid clonal propagation of Plumbago zeylancia. Plant groth Regul 1999; 28: 1-4. http://dx .doi.org/10.1023/A:1006146713143

13. Sharma N, Chandel KPS, Paul. In vitro propagation of Gentiana kurroo: an indigenous threatened plant of medicinal importance. Plant Cell Tiss. Org. Cult 1993; 34: 307-9. http://dx.doi.org/10.1007 /BF00029722

14. Sharma TR, Singh BM. High frequency in vitro multiplication of disease free Zingber officinale Rose. Plant Cell Rep 1997; 17: 6872. http://dx.doi.org/10.1007/s002990050354

15. Shasany AK, Khanuja SPS, Dhawan S, Yadav V, Sharma S, Kumar S. High regenerative nature of Mentha arvensis internodes. J. Bio sci 1998; 23: 641-6. http://dx.doi.org/10.1007/BF02709177

16. Tsay HS, Gau TG, Chen CC. Rapid clonal propagation of Pinellia ternata by tissue culture. Plant Cell Rep 1989; 8: 450-4. http://dx.doi.org/10.1007/BF00269046

17. Hu CY, Wang PJ. Meristem shoot tip and bud culture. In: Evans DA, Sharp, WR, Ammirato PV, Yamada Y. eds. Handbook of plant cell culture, New York: Macmillan; 1983. p. 177-227.

18. Skirvin RM, Ghu MG, Rukhan II. An improved medium for the in vitro rooting of Harbrite peach, Proc, III State. Hort. Soc 1980; 113: 30-38.

19. Agretious TK, Martin KP, Hariharan M. In vitro colonal multiplication of Alpinia calcarata Rose. Phyto morphology 1996; 46: $133-8$.

20. Sunnichen VG, Shivanna KR. Micropropagation of Eremostachys superha: an endangered endemic species from India. Curr Sci 1998; 74: 699-702.

21. Verma S, Magotra R, Koul AK. In vitro multiplication of Eremurus persicus Boiss. (Liliaceae). Endangered species Phyto morphology 2002; 52: 315-21.

22. Mitra GC, Kaul KN. In vitro culture of root and stem callus of Rauwolfia serpentine Benth, for reserpine, Indian J. Exp, Biol 1964; 2: 49-51.

23. Haque R, Saha S, Bera T. Micropropagation of an important medicinal plant Chlorophytum borivilianum. Int. J. Ph. Sci 2009; 1(1): 153-63. (References not cited in main text)

Cite this article as:

Pal Minakshi, Sethi Neeraj, Kaura Sushila, Parle Milind. Plant regeneration studies in Safed musli (Chlorophytum sp.). Int. J. Res. Ayurveda Pharm. 2014;5(1):95-98 http://dx.doi.org/10.7897/2277$\underline{434305119}$. 